\title{
Predation on marine bryozoan colonies: taxa, traits and trophic groups
}

\author{
Scott Lidgard* \\ Department of Geology, Field Museum of Natural History, 1400 S. Lake Shore Dr., Chicago, Illinois 60605, USA
}

\begin{abstract}
While bryozoans are important components of marine benthic ecosystems, their significance as food has scarcely been considered in any comparative study. An analysis of the phylogenetic range of predators on bryozoan colonies was undertaken to elucidate relationships among different consumers. Functional feeding traits and diet categories were determined from literature sources and observations for 399 predator species. Multivariate analyses were used to identify groups of species that consume similar food resources and have related functional traits corresponding to finding, acquiring and ingesting prey. These analyses distinguished gradients among trophic groups based on dissimilar feeding mechanisms, body sizes, types of locomotion and dietary breadths. Co-occurrences of certain diet categories also emerged as important factors. Trophic groups were largely consistent with species clusters at different taxonomic ranks among the predator phyla. At one extreme, fishes and decapod crustaceans with large dietary breadths and body sizes, and crushing or tearing feeding mechanisms, appear to consume bryozoans as minor or even incidental parts of their diets. At another extreme, species of nudibranchs, pycnogonids, turbellarians, and certain polychaetes, small arthropods and nematodes that consume bryozoans do so primarily or exclusively. Their body sizes are comparatively smaller and they often have piercing and suctorial feeding mechanisms. These differences are associated by inference with different probabilities of antagonistic encounters and likelihoods of lethal or sublethal predation. The analyses provide a baseline for ecological and evolutionary comparisons, and a broader context for the questions, 'Who eats bryozoans, how, and how frequently?'.
\end{abstract}

KEY WORDS: Bryozoa $\cdot$ Predation $\cdot$ Trophic $\cdot$ Diet $\cdot$ Functional groups

Resale or republication not permitted without written consent of the publisher

\section{INTRODUCTION}

Despite the frequency of occurrence of bryozoans in many benthic communities, no comprehensive analysis has considered their importance as prey for other animals. This is not to say their consumption has gone unnoticed. Knowledge of bryozoan consumers is written from the perspective of predator diets: dietary lists, experiments and observations of the predators that are most actively studied and accessible. Studies typically focus on one or a few predatory and prey species in single geographic locations. Descriptive summaries of predation on bryozoans have appeared sporadically (Osburn 1921, Ryland 1976, Cook 1985, McKinney et al. 2003). Yet these summaries offer no consensus regarding principal consumers, frequency of bryozoans within predator diets, predator sizes and feeding mechanisms, or damage inflicted on colonies. Not surprisingly, these facts contribute to a patchy and perhaps even distorted understanding of predation on colonies.

Bryozoans are colonial, and nearly all are sessile as adults. Their interactions with predators differ somewhat from those of unitary, motile organisms. Colonies show ecological patterns of regeneration and tolerance to consumers more analogous to terrestrial plants than to most unitary animals (Jerling 1985, Hughes 2005). While carnivory in animals generally results in prey mortality, herbivory in plants is sublethal more often than it is lethal, and so it may be in larger bryozoan colonies. Following larval metamorphosis, new zooids are formed by asexual budding. The body cavities of zooids are mostly discrete from one another. Certain physiological connections among zooids are main- 
tained for nutrient transport. Resource allocation within the colony is labile, alternatively supporting growth, regeneration, defense and reproduction (Harvell \& Helling 1993, Iyengar \& Harvell 2002, Peck \& Barnes 2004, Hughes 2005). Feeding zooids are generally $1 \mathrm{~mm}$ or less in length. In contrast, maximum colony size varies by several orders of magnitude among taxa with different colony growth habits. Attacks on bryozoan colonies can be considered as a continuum from sublethal damage to part of a single zooid, to consumption of a zooid, to consumption of multiple zooids, to lethal consumption (McKinney et al. 2003). Fatal predation on larvae and recruits involves somewhat different sets of risks and an overlapping suite of predators (Lidgard in press).

Bryozoan predators differ in the breadth of their diets and the relative importance of specific prey species. The dietary fidelity of the predator can range from an individual colony to colonies of 1 species, closely or more distantly related species, other animals, and even other domains such as protists or plants. Bryozoans often comprise $<1 \%$ by volume of the diets of grazing omnivores, herbivores eating the algal or seagrass substrates of epiphytic colonies, or browsers pursuing mobile arthropods and other invertebrates on the surfaces of colonies. The dietary inclusion of bryozoans may also change for a given predator over that individual's life history, with changing seasons, habitats or the abundance of alternate food resources. Conversely, dietary fidelity may be extremely rigid. The life cycles of some predators (or parasites) apparently cannot be completed except in the presence of a particular bryozoan prey (Lambert \& Todd 1994). Irrespective of the primary target of the consumer, the damage inflicted on colonies has the potential to affect fitness.

Antagonistic relationships between predators and bryozoans are too diverse to be understood by taxonomic lists alone. These data are necessary, but not sufficient, to reveal patterns that can be generalized with confidence. In the absence of data on relative predator densities and frequency of encounters, comparative studies have used attributes of feeding mechanisms, morphology, life history and diet to infer functional feeding groups (Steneck \& Watling 1982, Steneck 2001). Functional analyses quantify traits in these categories for a suite of taxa, generally comparing them simultaneously in a multivariate ordination space or clustering algorithm (Bremner et al. 2003). The suite may circumscribe a narrow taxonomic domain (e.g. Lombarte et al. 2003) or many phyla (e.g. Luczkovich et al. 2002). While most such studies are conducted in a local domain of a single site, others assess predation-related traits across a geographic region or even the globe (Garrison \& Link 2000, Bellwood et al. 2002, Depczynski \& Bellwood 2003).
I adopt a functional group approach here, assessing patterns across large taxonomic and geographic domains. Rather than assuming the typical perspective of the predators, I reverse the perspective to that of bryozoan prey and evaluate their spectrum of consumers. There are trade-offs in this approach. Drawn from the literature and my own observations, the surveyed habitats, food resources, prey species and predator species do not all co-occur. Ecomorphological studies also yield imperfect representations of spatial, temporal and trophic niches, conditioned on the selection of predator attributes (Norton et al. 1995, Padilla \& Allen 2000). One compelling advantage is that the context of predator-prey relationships is far broader than is conceivable in experimental studies, even if these were possible in all the habitats bryozoans occupy. Given the patchiness in our knowledge, establishing a comparative context is fundamentally important to understanding the influence of predation on bryozoan ecology and evolution. This approach provides a relative baseline, enhancing further detailed studies of predator roles.

I use hierarchical cluster analysis and non-metric multidimensional scaling (NMDS) to infer groups related to 1 function, predation. I compare attributes directly relevant to this function (feeding mechanics, size, locomotion and diet composition) among predators and assess patterns of similarities and differences. I will show that (1) bryozoan predators are widely distributed phylogenetically and are non-uniform in terms of constituent genera and species among higher taxa, (2) distinct functional feeding groups exist and are separated by feeding traits as well as dietary composition, (3) functional feeding groups typically correspond with taxonomic groups, but these associations are emergent at different taxonomic ranks, and (4) where sufficient data exists, diets of these groups differ considerably in relative amounts compared to frequency of occurrences of bryozoan prey.

\section{MATERIALS AND METHODS}

Taxonomic and dietary data. Results are based solely on those species known to consume marine bryozoans. All of the higher taxa of predators documented here have other member species that are not bryozoan predators, and thus the discussion that follows focuses on similarities and differences among bryozoan-consuming subsets of these higher taxa, exclusive of their other species.

The diets of 399 species that consume marine bryozoans were obtained from a thorough search of the literature and from my own observations. Relevant data were found in 286 studies. A few consumers were 
not resolved to species level. In order to be included, studies had to meet several criteria. First, a predator taxon must have been identified as actually feeding on a bryozoan. Associations of potential predators and bryozoans without a direct statement of consumption were not included. Very few studies attributed observations of predation to personal communications with another researcher. Second, observations had to have occurred at a particular location or in a particular region. Third, prey had to be identified either as 'bryozoan', or by genus or species name.

The common denominator for analyses is the relationship between a predator-prey couple, consisting of a single consumer taxon and a bryozoan. Taxonomic names were recorded verbatim, and were revised subsequently in an attempt to reduce redundancy. A total of 723 independent observations of predator-prey couples were recorded. While the data summarized are more extensive than in any previous study, they are not comprehensive. This is particularly true for diet studies of nudibranch mollusks and fishes, for which the literature is especially large.

Diet categories. To compare predator diet composition and breadth, the presence or absence of prey in each of 21 categories was recorded for the predator in each predator-prey couple (Table 1). Because relative abundances of prey were unavailable for most studies, the binary matrix of predator species $\times$ prey category was used for multivariate analyses. Functional categories of prey have proven valuable in maximizing sample sizes among disparate taxa and studies, and for determining ecological patterns among consumers using a variety of statistical methods (e.g. Garrison \& Link 2000, Bulman et al. 2001, 2002, Platell \& Potter 2001, Luczkovich et al. 2002). Diet categories used here are based on a combination of taxonomic groups and habitat utilization of prey (e.g. benthic versus planktic small arthropods). Categories generally follow those in previous diet studies of fishes and macroinvertebrates. Taxonomic identification of prey varied among studies from named species to broader categories. Some studies acknowledged that mastication and digestion prohibited the identification of certain prey items beyond phylum or class. Categories were adjusted by trial and error in order to maximize the number of studies that could be accommodated while maintaining a sufficient number of categories at as fine a taxonomic level as possible. For example, rhodophytes, phaeophytes, chlorophytes and related taxa were categorized into coralline and fleshy algal categories, and benthic arthropod taxa into small and megabenthic categories.

Relative abundances of these categories within predator diets were recorded whenever possible. However, different reporting practices, collecting
Table 1. Non-bryozoan diet categories and major constituents. All categories were scored as presence/absence variables for all predator-prey couples. UNID was excluded from all analyses; SEDM was excluded from all analyses excepting Jaccard similarity coefficient calculations for diet category co-occurrences

\begin{tabular}{ll} 
Diet category & Major constituents \\
\hline ALGC & $\begin{array}{l}\text { Calcareous algae-crustose and articu- } \\
\text { lated forms }\end{array}$ \\
ALGF & $\begin{array}{l}\text { Chlorophytes, phaeophytes - filamen- } \\
\text { tous, foliose and leathery forms }\end{array}$ \\
GRAS & Seagrasses \\
UNIC & Bacteria, diatoms, foraminiferans \\
CNID & Benthic hydrozoans, coral polyps \\
CORL & Scleractinian corals \\
PORF & Porifera \\
TUNI & Ascidians \\
POLY & Polychaete annelids \\
OTHR & Platyhelminthes, nematodes, sipunculans \\
ARTS & Small benthic arthropods-isopods, \\
& amphipods, ostracods, pycnogonids, \\
undetermined crustaceans
\end{tabular}

methods, and sampling intensities among studies introduced their own biases. It was not feasible to eliminate even some of the most obvious ones. Some studies reported stomach contents from dozens of consumer individuals, whereas others sampled fewer than 10 or did not list the number of individuals examined. Studies of larger-sized consumers such as fishes, echinoderms and large arthropods listed stomach contents more often than other studies. Percentages within individual diets may have been recorded originally as percent weight or percent volume; these are combined here as rough equivalents. Percentage occurrence of prey categories, or the proportion of individuals containing a prey item irrespective of weight or volume, was also recorded whenever possible. Measures of relative amount of prey and relative occurrence of prey 
were seldom reported together in the same study, aside from studies on fish diets. Diets of smaller consumers, such as nudibranchs, were more often documented by field observations, laboratory observations or experiments than by gut contents. Very small consumers such as nematodes, gammarid amphipods, harpacticoid copepods or pycnogonids living epizoically on colonies were documented by laboratory observations. Few studies reported on these latter groups despite the fact that they are commonly associated with bryozoans collected from many habitats. Different collecting and observation methods also influenced depth ranges sampled for different consumer groups, although the overwhelming majority of collections occurred at very shallow depths (see 'Discussion').

Functional feeding traits. In functional ecology, trophic group analysis offers a complementary set of insights into predator-prey interactions (Steneck 2001, Bremner et al. 2003, Dumay et al. 2004). Relevant functional traits (Table 2) correspond to finding, acquiring and ingesting prey, as well as potential damage per attack on bryozoan colonies. Community response and function are not considered here. Selection of traits is tempered by the need for consistent determination among predator phyla and body plans, as well as among studies.

Body size of consumers has been shown to be an important variable in prior studies of parasitism and predation. Size differences have been related to motility, frequency of encounters with prey, dietary fidelity along a parasite to predator continuum, metabolic needs, ratios of predator:prey lifespans, and the mechanics of consumption. These factors influence the overall vulnerability of colonies and their ability to tolerate attacks. The relative importance of bryozoans within consumer diets can change as predators develop through different size classes and life stages; these differences were seldom reported. Thus, juveniles are included in the survey but are not distinguished from adults. Maximum body length was recorded from the original publication and scaled geometrically as a categorical variable. One notable exception is the use of carapace width rather than length for crabs and lobsters. The maximum lengthh for the lowest size class corresponds roughly to macrobenthic predators $(0.2 \mathrm{~cm})$. The smallest metazoan, fungal or microbial parasites were excluded from the survey as they are so poorly documented. Where maximum length was not reported, I sought other references on body length for individuals from the same area and, failing that, body length for the taxon irrespective of locale.

Feeding method refers here to the mechanics of attack, handling and processing of prey. Feeding
Table 2. Functional traits related to acquisition and processing of prey, and the character states of these traits. Traits were scored by numbered character state for all predatorprey couples. Size: maximal size; Loco: primary locomotion; Feed: feeding method; Diet: breadth of diet

\begin{tabular}{|c|c|c|}
\hline Trait & No. & Character state \\
\hline \multirow[t]{6}{*}{ Size } & 1 & $0.2-2 \mathrm{~cm}$ \\
\hline & 2 & $2.1-4 \mathrm{~cm}$ \\
\hline & 3 & $4.1-8 \mathrm{~cm}$ \\
\hline & 4 & $8.1-16 \mathrm{~cm}$ \\
\hline & 5 & $8.1-16 \mathrm{~cm}$ \\
\hline & 6 & $16.1-100 \mathrm{~cm}$ \\
\hline \multirow[t]{3}{*}{ Loco } & 1 & Crawling or creeping \\
\hline & 2 & Swimming \\
\hline & 3 & Crawling and swimming \\
\hline \multirow[t]{5}{*}{ Feed } & 1 & $\begin{array}{l}\text { Engulf and crush food organism, } \\
\text { ingesting it whole or in large } \\
\text { pieces }\end{array}$ \\
\hline & 2 & $\begin{array}{l}\text { Tear or shred food organism, } \\
\text { commonly ripping part into } \\
\text { pieces for ingestion }\end{array}$ \\
\hline & 3 & $\begin{array}{l}\text { Scrape or rasp food organism, } \\
\text { cutting part (or all) away from } \\
\text { body or substrate for ingestion }\end{array}$ \\
\hline & 4 & $\begin{array}{l}\text { Pierce body of food organism, } \\
\text { leaving much of body intact }\end{array}$ \\
\hline & 5 & $\begin{array}{l}\text { Ingest part (or all) of the soft } \\
\text { tissue of food organisms by } \\
\text { means of extraoral digestion }\end{array}$ \\
\hline \multirow[t]{5}{*}{ Diet } & 1 & 1 diet category \\
\hline & 2 & 2 diet categories \\
\hline & 3 & 3-4 diet categories \\
\hline & 4 & 5-8 diet categories \\
\hline & 5 & 9-18 diet categories \\
\hline
\end{tabular}

methods and scale are relevant to how much of the colony is consumed, and whether or not single predatory attacks are potentially sublethal or lethal. This trait may also be relevant to predator selectivity. Pycnogonids, some polychaetes, the nematode and many nudibranchs were coded as piercing feeders. These are likely to attack single zooids using suctorial feeding, and are generally in the smaller size classes. Fishes and the squid were coded as crushing prey. Most predator groups are intermediate in size and employ different feeding mechanisms - shredding: other arthropods; scraping or rasping: chitons, most non-nudibranch gastropods and many nudibranchs; extraoral digestion: turbellarians and most asteroids; and crushing: echinoids, ophiuroids and some asteroids.

The primary mode of locomotion also has obvious implications for access to a range of food resources 
and selectivity. Fishes and the squid occupy the largest size categories (as adults), and are the only ones whose locomotion was coded solely as swimming. Locomotion in decapods and small arthropods was coded as either crawling or both crawling and swimming. Species in the remaining groups were coded as predominantly crawling, although swimming can occur among some species in these groups, such as certain nudibranchs.

Diet breadth was scaled geometrically as a categorical variable. The number of diet categories recorded for a given predator species coarsely reflects its trophic generality. This trait is also potentially related to selectivity and the extent of food resources available to a predator. All of these functional feeding traits were analyzed as categorical variables in multivariate analyses. Finally, minimum and maximum depths at which consumers and prey were observed or collected were also recorded, and used in a post hoc consideration of potential biases. While functional feeding traits and diet categories utilized here do attain comparability and consistency across studies, cautions regarding a priori determination of functional groups and their potential effects on subsequent analysis (Blondel 2003) should nonetheless be kept in mind.

Cluster analysis. Separate cluster analyses were used to group predator species on the basis of diet categories and functional feeding traits. Dendrograms based on Bray-Curtis similarity matrices were produced with PC-ORD version 5 (McCune \& Mefford 1999) using the average linkage algorithm. The original binary diet matrix was revised to include all prey categories recorded in different studies for the same predator species. The category 'unidentifiable remains' was excluded from the analysis, and 'sediment' was not considered as a nutritive food source. This resulted in a final matrix of 381 predator species $\times$ 19 diet categories. Because the diet-based dendrogram revealed a complex structure, correlation analyses using the Jaccard dichotomy coefficient were performed with SYSTAT for Windows version 11 (SYSTAT 2004) to examine relationships among individual diet categories (including sediments) across all species. The same 381 species were used for a separate functional feeding trait dendrogram, and 4 traits were treated as categorical variables with different character states.

Recognition of groups is fraught with subjectivity in virtually any clustering algorithm. Both dendrograms were examined to select a point at which information explained begins to diminish as each branch node levels off, with groups selected arbitrarily at that point. Clusters were assessed visually by plotting species membership in higher taxonomic groups to evaluate taxonomic partitioning by diet categories and by func- tional feeding traits. Species coded for each variable were also plotted to evaluate correspondence of clusters to individual variables. A simple Mantel correlation was used to test the null hypothesis that the functional feeding trait and diet similarity matrices are unrelated. In order to estimate $p$-values for the Mantel test, a Monte Carlo randomization test was used, permuting the matrices for 10000 iterations.

Ordination. NMDS was performed on the same set of species used in the cluster analyses to provide complementary insights into the structure of predator associations. NMDS permits the combination of feeding traits and diet categories to be evaluated in the same ordination space as the predator species. Species codings for both data matrices were combined (381 species $\times 23$ diet categories and feeding traits). NMDS was performed using Bray-Curtis similarity in PC-ORD. Taxonomic partitioning was again evaluated by plotting species membership in higher taxonomic groups. The correspondence of individual diet categories and functional feeding traits was also evaluated by coplots of each variable. The relative consistency of patterns revealed by comparing results from clustering and NMDS provides a qualitative means of verification, and a more robust basis for interpreting functional, dietary and taxonomic relationships, than either method used alone.

Interpretation of data from such varied sources may or may not precisely predict a specific instance of antagonistic interaction between a given predator and prey species or for species at any one specific locale or specific habitat. Rather, these analyses provide a common context for understanding interactions potentially occurring across a range of environments and taxa. Finally, I include some post hoc considerations using locality information and other data to illuminate sampling biases and areas where future studies could help clarify the results.

\section{RESULTS}

\section{Taxonomic distribution of colony predators}

The survey revealed an extraordinary phylogenetic diversity of reported bryozoan colony predators (Table 3). This diversity spanned 136 families in 8 phyla, although the distribution of genera and species among taxa was non-uniform. Gastropods were reported most frequently at about $33 \%$ of all species, followed by actinopterygian fishes $(26 \%)$, echinoids $(16 \%)$, malacostracans $(8 \%)$, asteroids $(7 \%)$, chitons $(4 \%)$ and polychaetes $(2 \%)$. Nudibranchs predominated over other gastropods, comprising $29 \%$ of all species. Most nudibranch species are in the families 
Table 3. Distribution of bryozoan colony predators in terms of taxonomic richness at various hierarchical ranks. Totals for predator-prey couples exclude species in Hydromedusae, Holothuroidea, Chondrychthii and Aves, but do include as yet undetermined species in other major taxa as reported in a few studies. Additional species were subsequently excluded from the analyses due to the nature of the studies that reported them (see 'Results')

\begin{tabular}{|c|c|c|c|c|}
\hline $\begin{array}{l}\text { Major predator } \\
\text { taxon }\end{array}$ & Families & Genera & Species & $\begin{array}{c}\% \text { of total } \\
\text { species }\end{array}$ \\
\hline \multicolumn{5}{|l|}{ Cnidaria } \\
\hline Hydroidomedusae & 1 & 1 & 1 & 0 \\
\hline \multicolumn{5}{|l|}{ Platyhelminthes } \\
\hline Turbellaria & 2 & 2 & 2 & 0 \\
\hline \multicolumn{5}{|l|}{ Nemata } \\
\hline Adenophorea & 1 & 1 & 2 & 0 \\
\hline \multicolumn{5}{|l|}{ Annelida } \\
\hline Polychaeta & 3 & 5 & 8 & 2 \\
\hline \multicolumn{5}{|l|}{ Arthropoda } \\
\hline Pycnogonida & 4 & 4 & 4 & 1 \\
\hline Malacostraca & 23 & 32 & 34 & 8 \\
\hline Maxillopoda & 1 & 1 & 1 & 0 \\
\hline \multicolumn{5}{|l|}{ Mollusca } \\
\hline Polyplacophora & 5 & 7 & 15 & 4 \\
\hline Gastropoda & 24 & 51 & 132 & 33 \\
\hline Cephalopoda & 1 & 1 & 1 & 0 \\
\hline \multicolumn{5}{|l|}{ Echinodermata } \\
\hline Echinoidea & 14 & 38 & 65 & 16 \\
\hline Asteroidea & 12 & 23 & 27 & 7 \\
\hline Ophiuroidea & 3 & 3 & 3 & 1 \\
\hline Holothuroidea & 1 & 1 & 1 & 0 \\
\hline \multicolumn{5}{|l|}{ Chordata } \\
\hline Chondrychthii & 1 & 1 & 1 & 0 \\
\hline Actinopterygii & 39 & 78 & 105 & 26 \\
\hline Aves & 1 & 1 & 2 & 0 \\
\hline Total & 136 & 250 & 404 & \\
\hline
\end{tabular}

Polyceridae, Onchidoridae, Goniodoridae and Proctonotidae, some of whose species were already well known as bryozoan predators (Miller 1961, Nybakken \& McDonald 1981, Todd 1981, Catteneo Vietti \& Balduzzi 1991). Non-nudibranch gastropods include trochids, littorinids and cypraeids, among others. Fish species are common in the suborders Labroidei (especially Labridae and Embiotocidae), Percoidei (especially Sparidae), Balistoidei (especially Monacanthidae) and Tetraodontoidei. Echinoid species that consume bryozoans are primarily in the families Cidaridae, Echinometridae, Temnopleuridae and Diadematidae, but are also distributed among 10 other families (De Ridder \& Lawrence 1982). Malacostracans are primarily decapod crabs and a few shrimps, and amphipods. Seastar species are fairly evenly distributed among families, with Asteriidae and Aster- inidae most prominent (Jangoux 1982). Chitons are primarily in the families Mopaliidae and Chitonidae, and polychaetes in the families Nereidae and Syllidae.

Most predator genera and species were each recorded in only 1 or 2 studies. This lack of redundancy suggests that while the survey results are the most inclusive categorization presently attainable, they are purely an approximation of the phylogenetic distribution of colony predators. Several higher taxa are undoubtedly under-represented by species in published studies. Ryland (1976, p. 417) stated, 'Of marine arthropods, pycnogonids are the most important consumers of bryozoans'. This view accords with their frequent association with bryozoans collected from both shallow and deep habitats and with cryptic coloration of many pycnogonids on individual shallow-water bryozoan species. Yet the small number of reports on pycnogonids consuming bryozoans scarcely bolsters the inference. Similarly, harpacticoid copepods, amphipods and nematodes are exceptionally common bryozoan associates (Excoffon et al. 1999, Conradi et al. 2000) and some do feed on bryozoan polypides (pers. obs.), but such antagonistic interactions are seldom reported.

The survey revealed some surprising bryozoan predators. Osburn (1921) reported sea ducks whose guts contained bryozoans, probably consumed incidentally with mollusks on which the colonies grew. Isopod predation on colonies was described by Dearborn (1967) and Buss \& Iverson (1981). Ophiuroids, more commonly considered scavengers and filter feeders, are reported as bryozoan predators by several authors (Pentreath 1970, Gordon 1972, Dearborn et al. 1996). Piraino et al. (1992) describe an ectoparasitic hydroid whose stolons grow between adjacent zooids on a bryozoan colony surface. The hydroid uses its tentacles to grasp and tear the lophophores of adjacent bryozoan zooids before ingesting them.

\section{Diet similarities in cluster analysis}

Three larger predator species clusters and 6 very small ones are apparent, with approximately $20 \%$ of information accounted for. The largest contains virtually all nudibranchs and other gastropods, polychaetes, turbellarians, pycnogonids, amphipods, and smaller subgoups of other taxa. Nudibranchs, 'worms' (an artificially construed group including turbellarians, polychaetes and a nematode), asteroids, echinoids and chitons are each subgroups in this cluster, mostly discrete from one another. The second, next largest cluster is dominated by fishes, with decapods as a much smaller and partially distinct subgroup. 
Some echinoids and asteroids are dispersed within the second cluster. The third largest cluster is much smaller than the first 2, and is dominated by echinoids and chitons. The remaining, smaller clusters are mostly mixes of fishes, decapods and other taxa. Clustering is generally a balance between finding a minimum number of discrete groups and the amount of information remaining in their similarity structure. With the large number of dimensions (diet categories), disparate diets among bryozoan predators, prey abundances among habitats, and sampling intensities among studies included here, variability among those species having more than 1 or 2 non-bryozoan diet categories is to be expected (Fig. 1).

To examine further the relationships between diet categories and predators, the proportional occurrence for each diet category within several predator groups was calculated (Table 4). Correlations were calculated among non-bryozoan diet categories among species in each of these taxa using the Jaccard dichotomy coefficient. This distance measure indicates the proportional occurrence of 2 diet categories, given the occurrence of one of them. Since all these species consume bryozoans, correlation with 'bryozoa' was not measured. Some taxa are partitioned or combined here to yield sufficient sample sizes (species) and to reflect patterns in the dendrogram. The most striking dissimilarity among these groups is the relative absence of nonbryozoan prey among nudibranchs, turbellarians, a nematode and some of the polychaetes in the survey versus the much greater breadth of diet among fishes and decapods. Visual comparison of dendrograms coded for the presence of individual diet categories with a dendrogram coded for predator species within taxonomic groups validated the general correspondence of the stronger correlations between diet categories and closely clustered species.

\section{Functional trait similarities in cluster analysis}

Cluster analysis based on feeding traits resolved 3 large clusters and 5 smaller ones at a level accounting for just less than $50 \%$ of information remaining. The largest cluster comprised nearly all nudibranchs, with a few polychaetes, a nematode and a non-nudibranch gastropod. The second largest cluster comprised nearly all fish species with scarce asteroids and echinoids. The third largest cluster principally comprised echinoids and decapod crustaceans as somewhat discrete subgroups, with scattered chitons, asteroids and other taxa. Smaller clusters were dominated by asteroids, decapods and small arthropods, chitons and nonnudibranch gastropods, pycnogonids, and echinoderms and a few nereid polychaetes, respectively.
Co-plots of the individual traits indicated that clusters were structured strongly by feeding mechanism, locomotion and diet. Size categories and diet categories indicating greater dietary breadth showed consistent trends across clusters, but were not as consistent within clusters. Part of this pattern can be attributed to higher variance among species within predator groups for these latter traits. While maximum body size does change in a very pronounced pattern across groups (Fig. 2), body sizes overall range through several orders of magnitude.

A null hypothesis of no relationship between the similarity matrices based on diet categories and on functional feeding traits was tested using a simple Mantel test. The 2 matrices were found to be positively related $(\mathrm{r}=0.37, \mathrm{p}=0.001)$. The test also provided indirect support for the relationships among predator taxa designated by the cluster analyses, and the combined NMDS ordination.

\section{Ordination: combined diet categories and feeding traits}

Ordination of all predator species revealed a considerable gradient of predator feeding groups at the highest taxonomic ranks (Fig. 3). Although species in different phyla or classes do overlap, the central tendencies of group clusters are clearly discernable from one another. The NMDS result was best resolved as a 2-dimensional representation selected after 250 runs with real data and 250 randomized runs from among 1 to 6-dimensional solutions. Stress in this representation was moderate (16.87).

Fig. 4 shows the co-plot of individual diet categories and functional feeding traits in the same ordination space. The direction and distance of points from the origin gives an indication of the relationship and relative magnitude of each variable along each of the 2 axes. A strong dietary correlation is present along Axis 2. Specialization on bryozoans alone occurs in the upper portion of the ordination space, and very wide dietary breadth in the lower portion. Feeding mechanisms are correlated with both axes. The overall pattern extends from piercing in the upper right quadrant, through scraping and rasping, then extraoral digestion, then shredding in the lower central region, through crushing in the lower left quadrant. Locomotion is also correlated with both axes. Movement by swimming partly separates the fishes and cephalopod in the lower left quadrant from highly overlapped distributions of species that either crawl or both crawl and swim. Sizes of species are correlated most strongly with Axis 1. A size gradient extends from smallest at the right to largest at the left, 

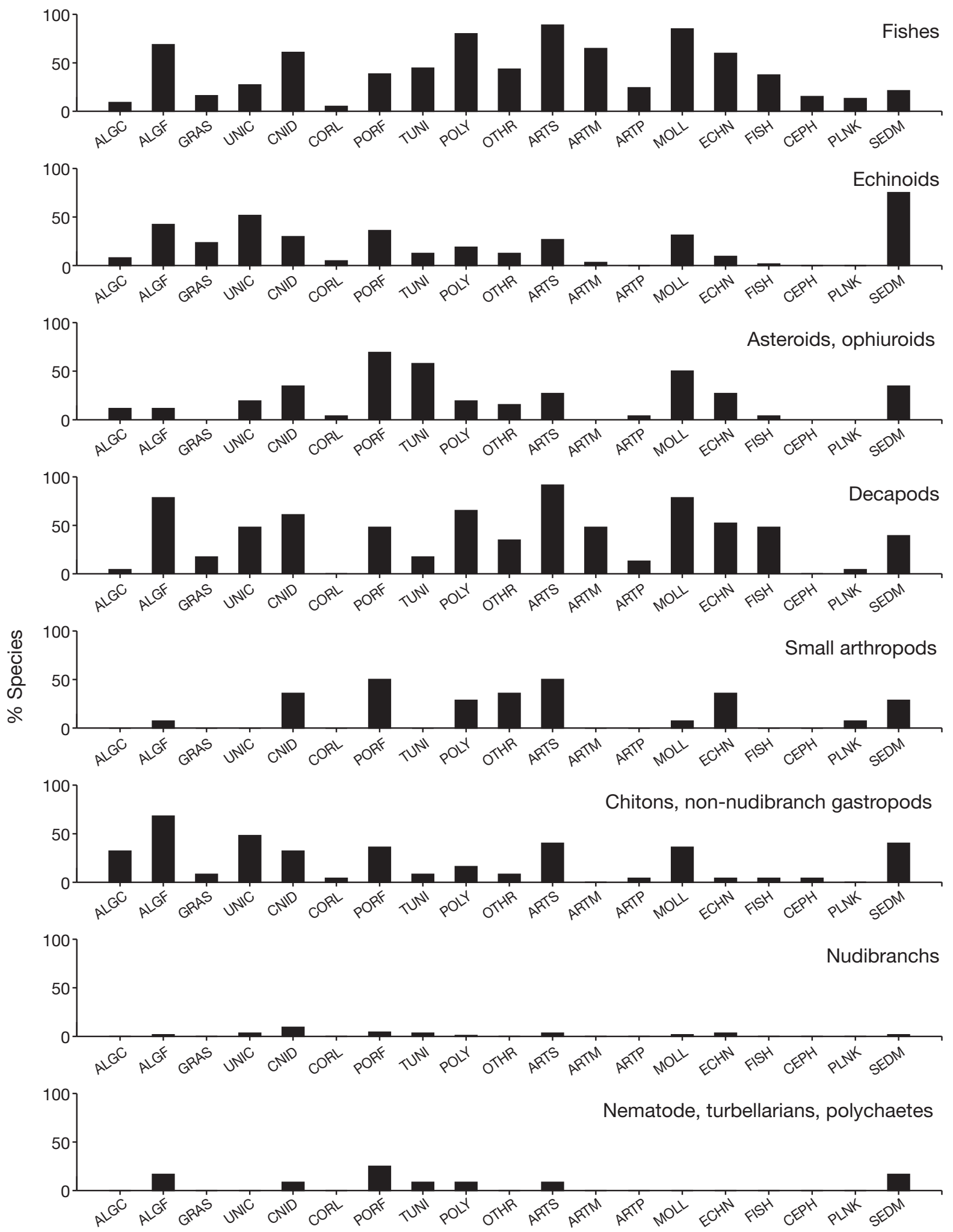

Diet categories

Fig 1. Frequencies of non-bryozoan diet categories among predator species. Each bar shows the percentage occurrence of a diet category among species in a given taxonomic group; see Table 1 for category abbreviations. Bryozoans are not included, as they occur in all predator diets in the survey 
Table 4. Proportional occurrence for each diet category within several predator groups. Certain groups of bryozoan predators may be differentiated by strong patterns of co-occurrence among non-bryozoan diet categories. Species diets were analyzed in each of these selected groups using the Jaccard dichotomy coefficient. A coefficient value $>0.5$ is used here as a minimum level of association, indicating relatively strong pairwise occurrence of 2 diet categories in a species' diet, given the occurrence of 1 of these categories. The predator group 'Worms' includes turbellarians, polychaetes and a nematode. The number of species ( $\mathrm{N})$ in each group is indicated. Diet categories (see Table 1 for definitions) that show relatively strong patterns of co-occurrence among species' diets are listed in pairs

\begin{tabular}{|c|c|c|}
\hline Predator group & $\mathrm{N}$ & Co-occurrence of non-bryozoan diet categories \\
\hline 'Worms' & 12 & None $>0.5$ \\
\hline Nudibranch gastropods & 118 & None $>0.5$ \\
\hline $\begin{array}{l}\text { Chitons and non- } \\
\text { nudibranch gastropods }\end{array}$ & 24 & $\mathrm{UNIC} \times \mathrm{ALGF}, \mathrm{UNIC} \times \mathrm{CNID}, \mathrm{CORL} \times \mathrm{ECHN}, \mathrm{MOLL} \times \mathrm{ARTS}$ \\
\hline Asteroids and ophiuroids & 26 & PORF $\times$ TUNI, OTHR $\times$ ARTS \\
\hline Echinoids & 64 & $\mathrm{UNIC} \times \mathrm{SEDM}, \mathrm{ALGF} \times \mathrm{GRAS}, \mathrm{ALGF} \times \mathrm{ARTS}$ \\
\hline Decapod crustaceans & 23 & $\begin{array}{l}\mathrm{UNIC} \times \mathrm{PORF}, \mathrm{ALGF} \times \mathrm{MOLL}, \mathrm{ALGF} \times \mathrm{ARTS}, \mathrm{ALGF} \times \mathrm{ECHN}, \mathrm{PORF} \times \mathrm{OTHR}, \\
\mathrm{PORF} \times \mathrm{ARTS}, \mathrm{CNID} \times \mathrm{POLY}, \mathrm{CNID} \times \mathrm{MOLL}, \mathrm{CNID} \times \mathrm{ARTS}, \mathrm{POLY} \times \mathrm{MOLL}, \mathrm{POLY} \times \mathrm{ARTS}, \\
\mathrm{POLY} \times \mathrm{ARTM}, \mathrm{MOLL} \times \mathrm{ARTS}, \mathrm{MOLL} \times \mathrm{ARTM}, \mathrm{ARTS} \times \mathrm{ECHN}, \mathrm{ARTM} \times \mathrm{SEDM}\end{array}$ \\
\hline Fishes & 99 & $\begin{array}{l}\mathrm{ALGF} \times \mathrm{CNID}, \mathrm{ALGF} \times \mathrm{POLY}, \mathrm{ALGF} \times \mathrm{MOLL}, \mathrm{ALGF} \times \mathrm{ARTS}, \mathrm{PORF} \times \mathrm{TUNI}, \mathrm{CNID} \times \mathrm{POLY}, \\
\mathrm{CNID} \times \mathrm{MOLL}, \mathrm{CNID} \times \mathrm{ARTS}, \mathrm{POLY} \times \mathrm{MOLL}, \mathrm{POLY} \times \mathrm{ARTS}, \mathrm{POLY} \times \mathrm{ARTM}, \\
\mathrm{POLY} \times \mathrm{ECHN}, \mathrm{MOLL} \times \mathrm{ARTS}, \mathrm{MOLL} \times \mathrm{ARTM}, \mathrm{MOLL} \times \mathrm{ECHN}, \mathrm{ARTS} \times \mathrm{ARTM}, \\
\mathrm{ARTS} \times \mathrm{ECHN}, \mathrm{ARTM} \times \mathrm{ECHN}\end{array}$ \\
\hline
\end{tabular}

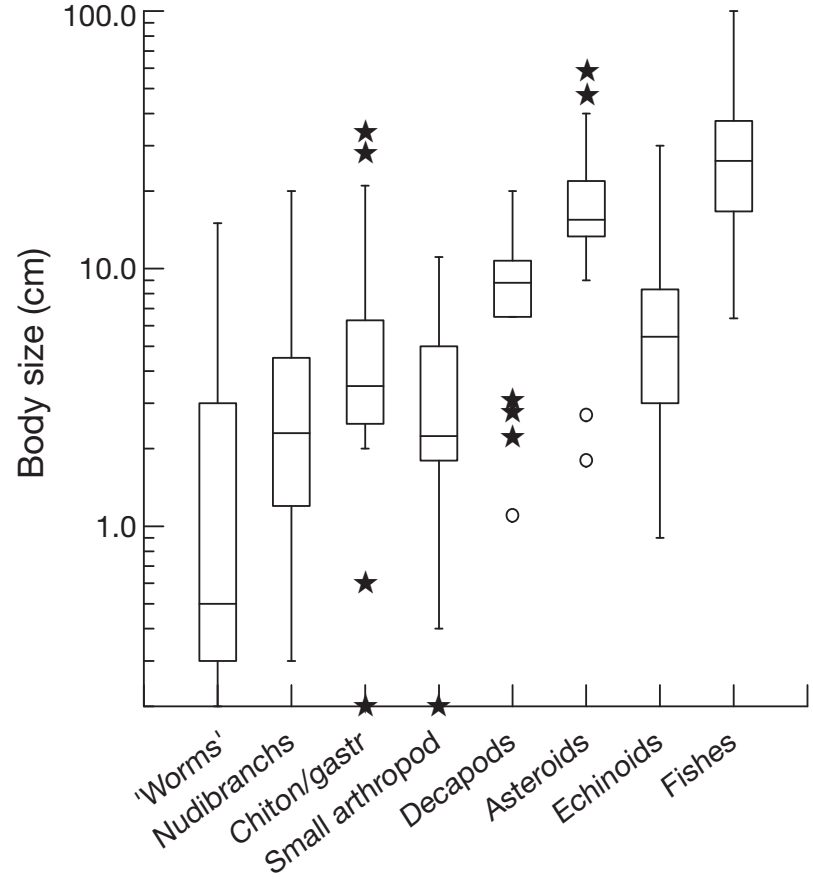

\section{Predator Groups}

Fig 2. Maximum sizes of bryozoan colony predators shown as a box-and-whiskers graph. Box shows the median value and the range of the central $50 \%$ of observations; vertical whiskers surround observations that fall within the next $1.5 \times$ central-range; $\star$ shows outliers within $3.0 \times$ centralrange, and $\mathrm{O}$ shows outliers beyond $3.0 \times$ central-range. The predator group 'Worms' includes a nematode, polychaetes and turbellarians. Note logarithmic scale of size.

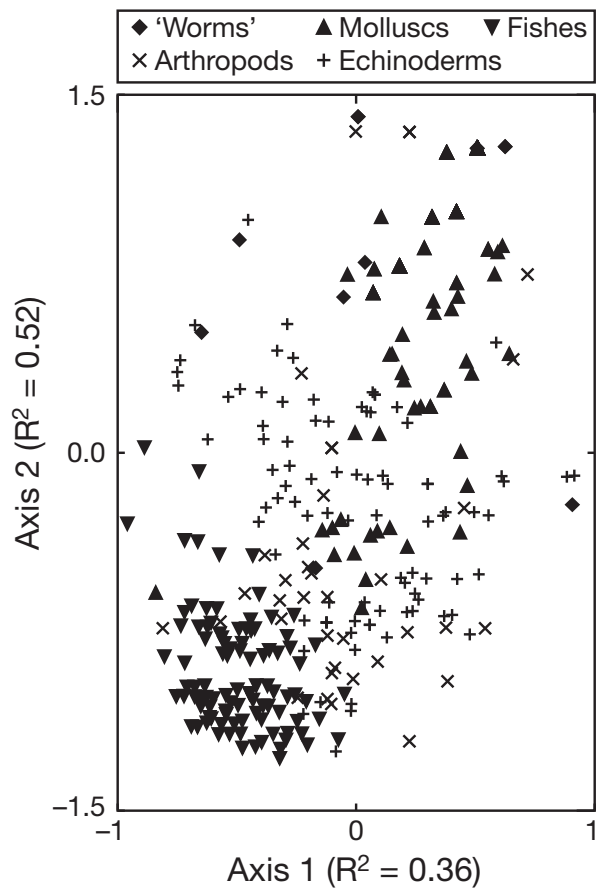

Fig. 3. Nonmetric multidimensional scaling (NMDS) ordination for bryozoan colony predators, based on Bray-Curtis distances of diet categories and functional traits. Symbols distinguish arthropods, echinoderms, fishes, mollusks and 'worms' (nematode, polychaetes and turbellarians). For each axis, $\mathrm{R}^{2}$ values are coefficients of determination between ordination distances and the original unreduced distance space (cumulative $\mathrm{R}^{2}=0.877$ ). The coefficients provide a relative accounting of the variance explained by these axes 


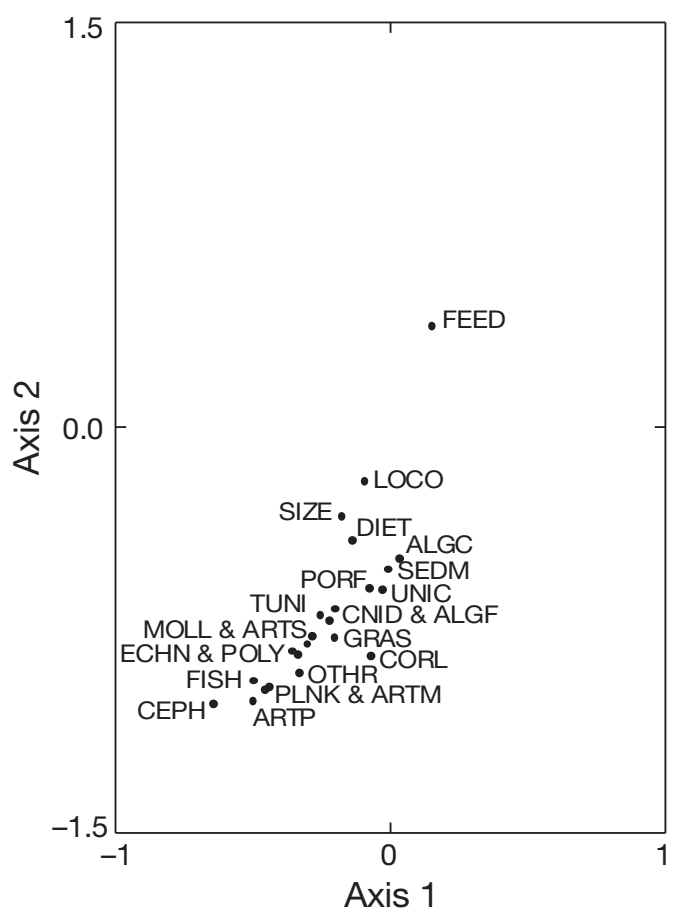

Fig. 4. Co-plot of the NMDS ordination space with diet categories and functional traits. Position of points relative to the origin indicates direction and magnitude of these variables on the ordination axes. Categories and traits are shown in Tables 1 \& 2 cients among diet categories. The diet categories also helped differentiate chitons from non-nudibranch gastropods by the frequent occurrence of calcareous and fleshy algae in chiton species. Certain asteroids with extraoral digestion are differentiated by the co-occurrence of tunicates and porifera in their diets. Camarodont echinoids with larger body sizes and frequent presence of algae and seagrasses, polychaetes and small arthropods in their diets are partly divided from cidaroids, which also frequently consumed sediment. Similarly, some subgroups of fishes have extremely large dietary breadth, and consume other fishes, cephalopods and planktonic prey, or large benthic prey such as megabenthic arthropods and echinoderms that are defended by skeletal armament. These include many labrids and sparids, among others. Tetraodontiform species consumed coralline algae, coral and unicellular organisms more frequently than other fish subgroups, and these species seldom consumed cephalopods or other fishes. The predator group including small arthropods is further split by the greater dietary breadth and body sizes of some large Antarctic amphipods, and the narrow dietary breadth of pycnogonids. Finally, the artificial predator group 'worms' is differentiated by the larger differences in size and diet composition in some nereid polychaete species. although there is extensive overlap of species within the largest size classes (Table 2). Feeding categories coral, porifera, unicellular organisms, sediment and calcareous algae are correlated with Axis 2. The remaining diet categories are correlated with both axes, but with the larger magnitudes on Axis 2 in the lower left quadrant for fishes and cephalopods, planktic taxa, echinoderms, polychaetes, mollusks and benthic arthropods.

The proximity of predator groups at intermediate taxonomic ranks in the same ordination space clarifies their relationships further (Fig. 5). Co-plots of individual functional feeding traits all validated the pattern of clustering to a greater degree than for higher taxonomic ranks, as did comparisons with the clusters revealed by the feeding trait dendrogram. Co-plots of individual diet categories showed concentrations matching their proportional occurrence in Fig. 1. These concentrations also reflected the larger clusters in the diet category cluster analysis, and the Jaccard dichotomy coeffi-

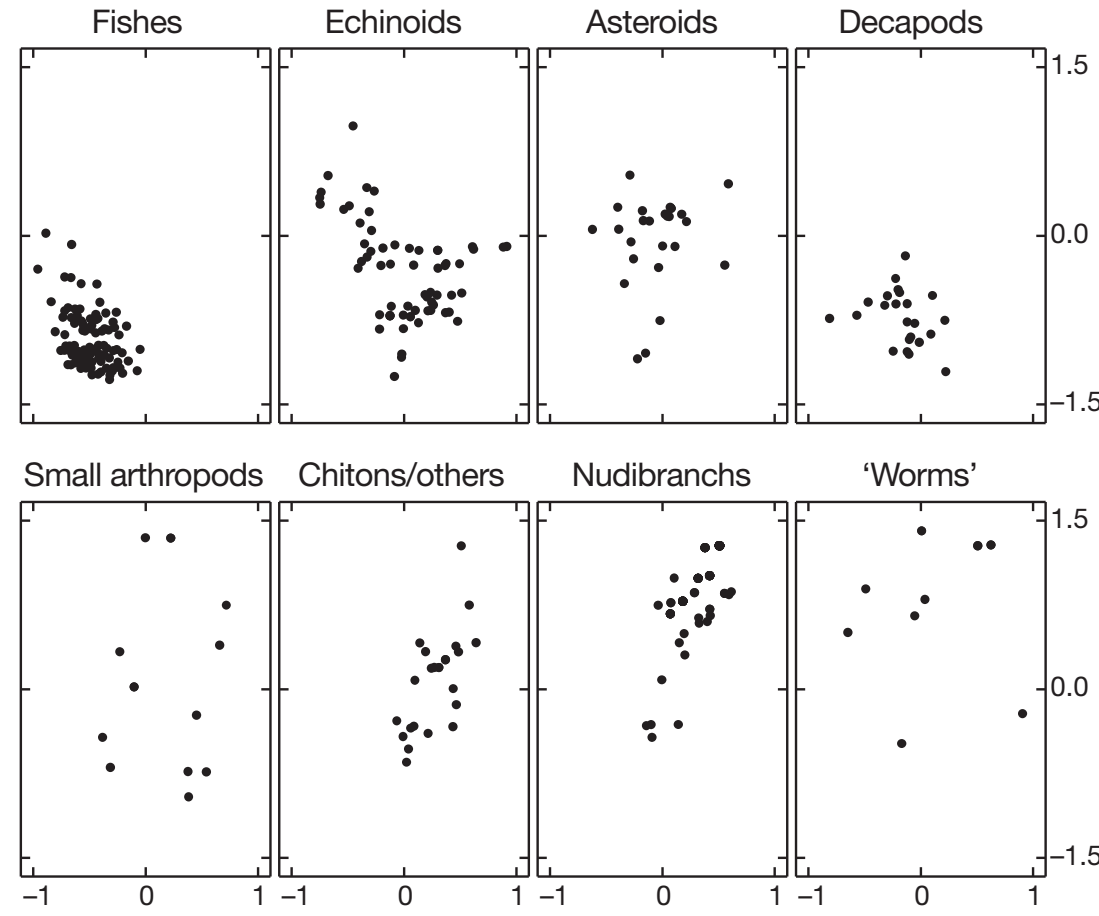

Fig. 5. Species within intermediate taxonomic groups are shown as separate plots of the NMDS ordination space. The distributions of most (though not all) of these taxonomic groups are resolved more distinctly as functional feeding groups. Subsequent reductions in taxonomic ranks for some taxa provide further resolution 


\section{Amount and frequency of bryozoans in predator diets}

When the amounts and relative frequencies of bryozoans in predator diets are taken into account, they indicate tendencies in diet selectivity (Fig. 6). Most such records are based on gut contents of arthropods, echinoderms and fishes. Amount is the average proportion of bryozoans by either weight or volume in gut contents of sampled individuals within a species. Occurrence is the proportion of sampled individuals within a species that contained bryozoans, irrespective of amount. Amount and occurrence data subsets mostly come from different studies and different species for both arthropods and echinoderms. Thus, inferences based on comparing the 2 measures are indirect
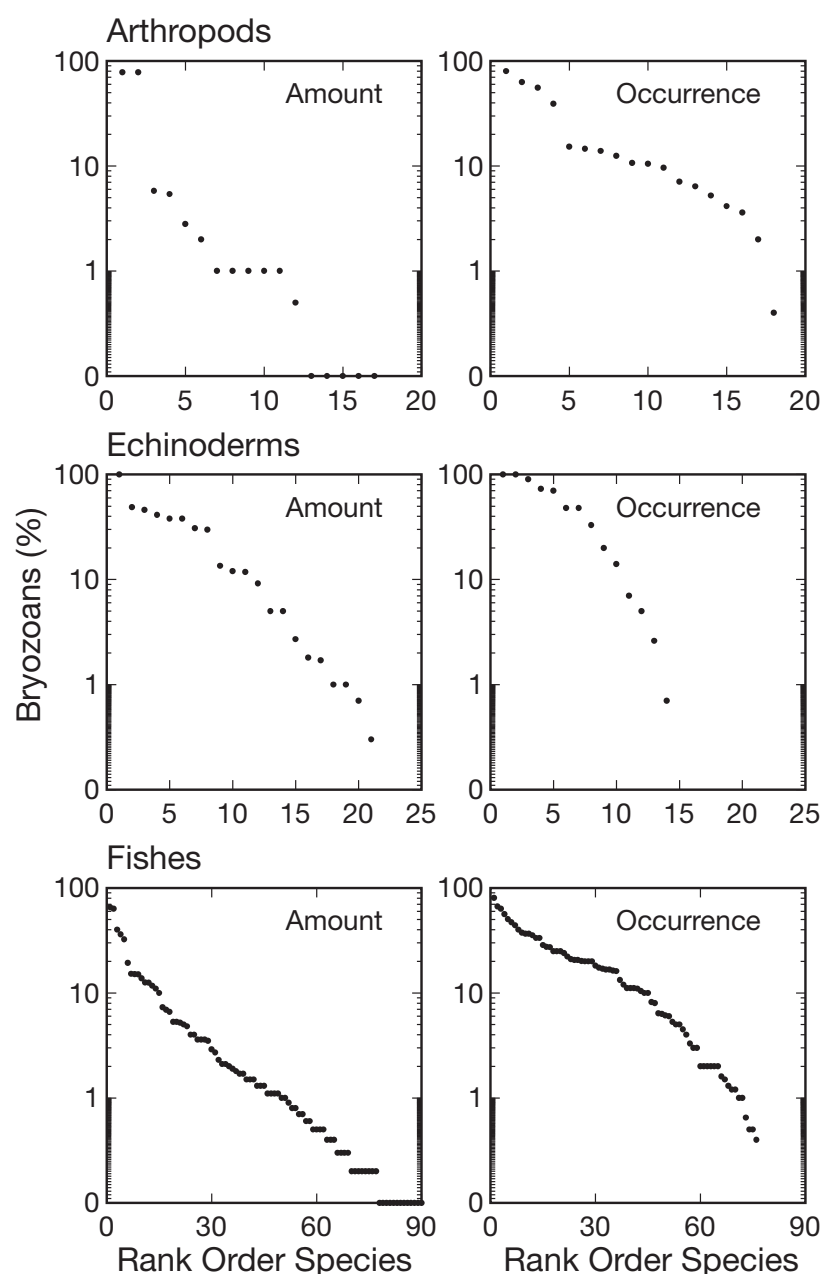

Fig. 6. Percentages of bryozoans in the diets of individual predator species are shown for a subset of studies that reported these data. Within each major predator group, percentages are arranged in rank order. For definition of 'amount' and 'occurrence' see 'Results: Amount and frequency of bryozoans in predator diets' for these taxa and should be considered accordingly. Most (but not all) of the amount and occurrence data for fishes were reported in the same set of studies, and therefore this comparison is more direct.

Bryozoans are a dominant or significant component in the diets of some species in all 3 taxa. However, for most species, the relative 'amount' of bryozoans is much lower than relative occurrences among species. For echinoderms, about half of the species had gut contents with $\geq 10 \%$ bryozoans. The amount of bryozoans was $<1 \%$ in diets of more than half of the species of arthropods and fishes. The proportional occurrence of bryozoans among individuals is significantly higher. Among fishes, bryozoans occurred in $10 \%$ or more of the individuals in about half of the species. This difference between the 2 measures suggests that for these taxa, most species that consume bryozoans may not do so selectively, at least to any great degree. More likely, bryozoans are consumed as part of a broader suite of prey items, either through browsing or relatively unselective grazing. To the extent that this inference holds true, bryozoans may be an ever more incidental dietary component.

\section{DISCUSSION}

\section{Sampling biases}

Despite the broad geographic and taxonomic domain of the survey and analyses, sampling biases remain a concern. While the range of reported predatory encounters extends beyond $1000 \mathrm{~m}$ in depth, the median depths for reports in each major predator group are between 5 and $25 \mathrm{~m}$. Since bryozoans attain their greatest diversity and abundance at middle to outer shelf depths, we must extrapolate our observations from the shallow subtidal zone to deeper habitats which may have rather different patterns of predator dominance. It was also impossible to distinguish the relative importance of juvenile versus adult predators across groups. Small juveniles of many taxa may consume bryozoans, and this remains unreported, save for a few scattered observations. Birkeland et al. (1971) reported feeding of a newly metamorphosed seastar on single bryozoan zooids. Cook (1985) offered a summarizing statement to the effect that small predators of bryozoans have been neglected relative to large ones. This under-representation still holds true, perpetuated by the empirical difficulties of collecting and observing small marine organisms on colony surfaces. Taking these concerns into account, the patterns revealed in the present study should be viewed as general, and as a first approximation that will continue to be clarified by additions and refinements. 


\section{Feeding patterns of predator groups}

The present study produced a fairly comprehensive summary of the diversity of bryozoan predators and revealed some significant patterns in their respective feeding-related traits and diets. Fishes that consume bryozoans typically have a large dietary breadth with a median of 9 dietary categories consumed (Fig. 1). This compares to 8 categories in decapods, 5 in chitons, 4 each in echinoids, asteroids and non-nudibranch gastropods, 3 in small arthropods and 1 (bryozoans) in 'worms' and nudibranchs. Maximum sizes of fishes are also generally larger than those in other predator groups, and their greater mobility gives them access to a wide variety of food resources. Over $90 \%$ of the fish species are durophagous to some degree, in that they consume armored invertebrate prey such as shelled mollusks, echinoderms, megabenthic arthropods or coral skeleton.

Durophagous fishes typically have hypertrophied jaw muscles and crushing oral or pharyngeal jaws. Skeletal armament of prey is crushed and often processed to separate nutritive from non-nutritive material. Using the terminology of Wainwright \& Bellwood (2002), about $65 \%$ of these species capture prey by manipulation, where prey is removed by the jaws applied directly to the substratum. Many bryozoan-consuming species have a modified secondary pharyngeal apparatus, such as in labrids, serranids and sparids. Another $25 \%$ of species combine ram and suction feeding, in which the body lunges forward and jaws are protruded to capture prey while suction from expansion of the buccal cavity draws prey into the mouth. Some of the remaining species more often pick small invertebrates from the water column or on or near the substrate. The diet patterns, functional feeding morphologies and comparison of relative amount and occurrence of bryozoans in various species indicate that most fishes in the present study are browsers, taking bryozoans as minor dietary components. For many, bryozoans may be incidental by-catch in their pursuit of other invertebrates living on the bryozoan colonies.

Epibionts are common on colony surfaces (Gordon 1972, Morgado \& Tanaka 2001) and small mobile invertebrates and juvenile fishes are abundant and important prey for fishes in bryozoan-rich benthic habitats (Bradstock \& Gordon 1983, Taylor 1998, Cole 1999). One study of epibionts on large erect colonies estimated up to 83 organisms per g dry weight bryozoan colony (Pederson \& Peterson 2002). In an analogous pattern, some fish groups such as blennies and balistids are primarily herbivorous or omnivorous, yet may consume considerable amounts of bryozoans growing as epibionts on macroalgae or seagrasses.

Crabs and other decapod crustaceans also exhibit large breadth of diet. Most are omnivorous predators, capturing their prey with the claws of their cheilipeds by crushing or tearing, then shredding it further with their maxillipeds. Bryozoans were minor components in the diets of the species reported, often subsidiary to other benthic colonial organisms. As with some fishes, decapods may consume bryozoans together with other prey including algae or seagrasses on which colonies grow. The predator group of small arthropods is diverse in its breadth of diet, with pycnogonids, a copepod, and small amphipods reported to feed on bryozoans alone, often one zooid at a time. The pycnogonids pierce their prey and suck the tissue from within the zooecium. Some small amphipods and copepods tear or bite at soft tissue of lophophores or uncalcified zooid body walls. Gut contents of some unusually large gammarid amphipods from deep-water Antarctic habitats contain a variety of benthic animals, including echinoderms (Dauby et al. $2001 a, b)$. However, the average content of one of these gammarid species was exclusively bryozoans.

The echinoids in the present survey are primarily grazing predators on algae and sessile animals. They use their Aristotle's lanterns to crush and grind their benthic prey, including bryozoans living on hard substrates and on fleshy algae. The regular presence of sediments in species' diets shows their propensity to clear hard surfaces. Bryozoans can sometimes comprise large parts of their diets (Strenger \& Splechtna 1978) but surface grazing also results in consumption of most attached benthic organisms. Echinoid feeding preferences may also be influenced positively by the presence of sessile epibionts including bryozoans (Wahl \& Hay 1995, Wahl et al. 1997). The asteroids in the survey were primarily carnivores on sessile benthic animals, particularly colonial taxa. Some asteroids, as well as ophiuroids, swallow prey whole or crush it with their arms and teeth; other asteroids evert the stomach to engulf the prey and digest soft tissues externally. In most instances, bryozoans were one part of a moderately broad diet.

Chitons, not unlike some echinoids, graze hard substrates and consume a variety of calcareous and fleshy algae, unicellular organisms, and sessile benthos. They are generalist grazers that creep along the substrate and use their large, well developed radula to rasp or scrape the indigestible substrate as well as most anything attached to it. Encrusting bryozoans appear to be one among many sessile organisms on hard substrates that are preyed upon in this manner. Consequently the relative abundance of bryozoans in diets of certain chiton species is above $10 \%$. Some of the prosobranch gastropods in the analysis are also grazing predators for which bryozoans are only one part of a broader diet. An exception to this pattern may be Cystiscus (Microginella) minutissima, which appears to consume only a single host bryozoan (Murray 1970). 
The nudibranchs in the present study mostly feed on bryozoans alone, or on a few other sessile colonial animals. However, their functional feeding patterns differ. Some species attack single zooids by piercing the body wall of individuals with a narrow radula and sucking out the nutritive contents, as in species of Corambidae and Onchidoridae. Other nudibranch species, notably many polycerids, scrape the radula through multiple zooids of encrusting or erect colonies and process the pieces through their mouths. Therefore, nudibranchs may be either single-zooid or multiple-zooid scale predators. One significant ecological tendency of these nudibranchs is the great extent to which species are reported feeding only on a single species of bryozoan. While not a uniform pattern, it is sufficiently well documented and distinguishes this group from nearly all large predator species and many less well-known small ones.

Single-zooid scale predators that appear to consume bryozoans exclusively or predominantly include turbellarian flatworms, a nematode, pycnogonids and most nudibranchs. This pattern also characterizes some polychaetes, amphipods, copepods and prosobranch gastropods. These predators tend to be small compared to maximum sizes of decapods, chitons, echinoderms and fishes. Most of these predators are carnivores, many tend to have comparatively low metabolic rates, and many are suctorial feeders on soft tissues and coelomic fluids. Feeding behaviors of some of these predators also involves circumventing skeletal armament by attacking fleshy everted polypides or boring through zooid body walls or orifices (Stekhoven 1933, Wyer \& King 1973, Buss \& Iverson 1981, Winston 1986a, CatteneoVietti \& Balduzzi 1991). There is not much 'meat' in a bryozoan zooid. Energy values of bryozoans tend to be comparatively low (Wacasey \& Atkinson 1987, Lippert \& Iken 2003), which may help to explain the small body sizes of bryozoan specialist predators, at least in an approximate energetic sense. Most bryozoans also calcify their body walls to various degrees, which may further diminish the potential nutritive value to predators that allocate energy to preferentially locating and processing bryozoans as food. These factors may relegate dietary specialization on bryozoans to a suboptimal energetic investment for large or metabolically active predators.

\section{Avoidance, defense or tolerance by bryozoan prey}

Susceptibility of colonies to consumer damage or mortality varies with the size of predators, the mechanism of attack and the likelihood of encounter (Lidgard in press). Predator species with larger body sizes and feeding mechanisms that destroy multiple zooids per attack pose a high risk of mortality, especially during early colony growth and for bryozoan species that never attain large sizes. However, if pursuit and capture of bryozoan prey is not a significant part of the feeding behavior of larger predators, the likelihood of antagonistic encounters may be considerably less than encounters with smaller and far more numerous mobile epibiont predators such as nudibranchs, nematodes, polychaetes and small arthropods. These smaller predators are likely to inflict less damage per attack.

As with many other ecological systems (Poitrineau et al. 2003), the selective forces of multiple predators and the relative investment in avoidance (selective recruitment), defense or tolerance of sublethal predation among bryozoan species have scarcely been investigated. We do not have robust estimates of relative abundances for different predator groups in bryozoanrich habitats or estimates of relative predation intensities. Most individual bryozoan colonies are also quite small, a significant impediment for any census of small predators in situ. It is also empirically difficult to measure frequencies of antagonistic interactions by taxon and consequent rates of colony damage sustained in the wild. While growth is potentially indeterminate, colonies in most taxa seldom attain sizes above 1 to a few $\mathrm{cm}$. As the colony persists in its sessile adult phase, the likelihood of encounter and attack by growing numbers of predators increases. In addition, as the colony increases in size, it is potentially more tolerant of tissue loss and more capable of regeneration, and therefore may be less susceptible to mortal injury in a single attack (Jackson \& Palumbi 1979, Walters \& Wethey 1991, Bone \& Keough 2005). Directional growth also carries the potential for reaching a partial refuge from many sources of mortality (Buss 1979).

Strong selective pressure by a predator species can be a determinant of bryozoan species distribution and abundance, at least on a local scale. Natural patterns of colony abundance sometimes show dramatic declines in the presence of a voracious predator species (Strenger \& Splechtna 1978). Manipulation of predator densities in caging experiments demonstrates similar effects (Mancinelli \& Rossi 2001). As a general pattern, many bryozoans selectively recruit or have higher survivorship as recruits in cryptic microhabitats such as concavities or the undersurfaces of corals or cobbles (Keough \& Downes 1982, Winston 1986b, Walters \& Wethey 1996). This avoidance behavior at early life-history stages can also preclude future access by larger predators.

Skeletal elaborations of the exposed zooid surface, such as calcified thickening, spines, ovicells or avicularia, can deter the feeding of small epibionts (Winston 1984, 1986a, Iyengar \& Harvell 2002, McKinney et al. 2003). These skeletal characteristics are the basis for much of traditional bryozoan taxonomy. Their changing frequencies among major subtaxa through geologic time determine large-scale evolutionary trends, 
with the inference of predation as a diffuse selective force (McKinney \& Jackson 1989). However, these defenses and the material strength of zooid skeletons offer trivial resistance against the mechanical forces generated by larger predators such as echinoids, decapods or fishes. Small predators causing sublethal damage to colonies are more likely determinants of these trends, and deserve more thorough investigation.

Only recently have we begun to explore the potential defensive roles of bryozoan-associated secondary metabolites (Sharp et al. 2007), which can be the products of bacterial symbionts. Some of these metabolites may serve as a chemical defense against colony predators. Larger predators undeterred by skeletal defenses may well avoid unpalatable or toxic bryozoan prey. However, these metabolites may play alternate ecological roles in defense of larvae (Lindquist \& Hay 1996) or deterrence of fouling organisms (Martin \& Uriz 1993) or overgrowth competitors. These evolutionary and ecological inferences raise the questions considered in this study, 'Who eats bryozoans, how, and how frequently?'. In this regard, bryozoans are hardly unique among marine benthic organisms.

Acknowledgements. This comparative study would not have been possible without the examination of predator diets conducted by hundreds of researchers who deserve praise for their work. E. Grey, D. P. Gordon, M. Kowalewski, L. Leighton, F. K. McKinney, B. Rudman, R. Strathmann, P. D. Taylor, C. Todd and M. Westneat discussed various aspects of the work. C. Pries and J. Porter provided useful criticism of the manuscript. I am grateful to all.

\section{LITERATURE CITED}

Bellwood DR, Wainwright PC, Fulton CJ, Hoey A (2002) Assembly rules and functional groups at global biogeographical scales. Funct Ecol 16:557-562

Birkeland C, Chia F, Strathmann R (1971) Development, substratum selection, delay of metamorphosis and growth in the seastar, Mediaster aequalis Stimpson. Biol Bull 141: 99-108

Blondel J (2003) Guilds or functional groups: does it matter? Oikos 100:223-231

Bone EK, Keough MJ (2005) Responses to damage in an arborescent bryozoan: effects of injury location. J Exp Mar Biol Ecol 324:127-140

Bradstock M, Gordon DP (1983) Coral-like bryozoan growths in Tasman Bay, and their protection to conserve commercial fish stocks. N Z J Mar Freshw Res 17:159-163

Bremner J, Rogers SI, Frid CLJ (2003) Assessing functional diversity in marine benthic ecosystems: a comparison of approaches. Mar Ecol Prog Ser 254:11-25

Bulman C, Althaus F, He X, Bax NJ, Williams A (2001) Diets and trophic guilds of demersal fishes of the south-eastern Australian shelf. Mar Freshw Res 52:537-548

Bulman CM, He X, Koslow JA (2002) Trophic ecology of the mid-slope demersal fish community off southern Tasmania, Australia. Mar Freshw Res 53:59-72

Buss LW (1979) Habitat selection, directional growth and spatial refuges: why colonial animals have more hiding places. In:
Larwood G, Rosen BR (eds) Biology and systematics of colonial organisms. Academic Press, New York, p 459-497

Buss LW, Iverson EW (1981) A new genus and species of Sphaeromatidae (Crustacea: Isopoda) with experiments and observations on its reproductive biology, interspecific interactions and color polymorphisms. Postilla 184:1-24

Catteneo Vietti R, Balduzzi A (1991) Relationship between radular morphology and food in the Doridina (Mollusca: Nudibranchia). Malacologia 32:211-217

Cole RG (1999) Trophic relationships between fishes and benthic organisms on northeastern New Zealand reefs. Vie Milieu Ser A Biol Mar 49:201-212

Conradi M, Lopez-Gonzalez PJ, Cervera JL, Garcia-Gomez JC (2000) Seasonality and spatial distribution of peracarids associated with the bryozoan Bugula neritina in Algeciras Bay, Spain. J Crustac Biol 20:334-349

Cook PL (1985) Bryozoa from Ghana - a preliminary survey. Zool Sci Annals, Vol 238. Royal Museum for Central Africa, Tervuren, Belgium

> Dauby P, Scailteur Y, Chapelle G, De Broyer C (2001a) Potential impact of the main benthic amphipods on the eastern Weddell Sea shelf ecosystem (Antarctica). Polar Biol 24: 657-662

> Dauby P, Scailteur Y, De Broyer C (2001b) Trophic diversity within the eastern Weddell Sea amphipod community. Hydrobiologia 443:69-86

De Ridder C, Lawrence JM (1982) Food and feeding mechanisms: Echinoidea. In: Jangoux M, Lawrence JM (eds) Echinoderm nutrition. A. A. Balkema, Rotterdam, p 57-115

Dearborn JH (1967) Food and reproduction of Glyptonotus antarcticus (Crustacea: Isopoda) at McMurdo Sound, Antarctica. Trans R Soc N Z Zool 8:163-168

Dearborn JH, Hendler G, Edwards KC (1996) The diet of Ophiosparte gigas (Echinodermata: Ophiuroidea) along the Antarctic Peninsula, with comments on its taxonomic status. Polar Biol 16:309-320

> Depczynski M, Bellwood DR (2003) The role of cryptobenthic reef fishes in coral reef trophodynamics. Mar Ecol Prog Ser 256:183-191

> Dumay O, Tari PS, Tomasini JA, Mouillot D (2004) Functional groups of lagoon fish species in Languedoc Roussillon, southern France. J Fish Biol 64:970-983

Excoffon AC, Genzano GN, Zamponi MO (1999) Macrobenthos associated with a population of Anthothoe chilensis (Lesson, 1830) (Cnidaria, Actiniaria) in Mar del Plata harbor, Argentina. Cienc Mar 25:177-191

Garrison LP, Link JS (2000) Dietary guild structure of the fish community in the Northeast United States continental shelf ecosystem. Mar Ecol Prog Ser 202:231-240

Gordon DP (1972) Biological relationships of an intertidal bryozoan population. J Nat Hist 6:503-514

Harvell CD, Helling R (1993) Experimental induction of localized reproduction in a marine bryozoan. Biol Bull 184: 286-295

Hughes RN (2005) Lessons in modularity: the evolutionary ecology of colonial invertebrates. Sci Mar 69:169-179

> Iyengar EV, Harvell CD (2002) Specificity of cues inducing defensive spines in the bryozoan Membranipora membranacea. Mar Ecol Prog Ser 225:205-218

Jackson JBC, Palumbi SR (1979) Regeneration and partial predation in cryptic coral reef environments: preliminary experiments on sponges and ectoprocts. In: Levi C, BouryEsnault N (eds) Biologie des spongiares. Colloques Internationaux du Centre National de la Recherche Scientifique, Paris. No. 291, p 303-308

Jangoux M (1982) Food and feeding mechanisms: Asteroidea. In: Jangoux M, Lawrence JM (eds) Echinoderm nutrition. A. A. Balkema, Rotterdam, p 117-159 
Jerling L (1985) Are plants and animals alike? A note on evolutionary plant population ecology. Oikos 45:150-153

Keough MJ, Downes BJ (1982) Recruitment of marine invertebrates: the role of active larval choices and early mortality. Oecologia 54:348-352

Lambert WJ, Todd CD (1994) Evidence for a water-borne cue inducing metamorphosis in the dorid nudibranch mollusc Adalaria proxima (Gastropoda: Nudibranchia). Mar Biol 120:265-271

Lidgard S (in press) How should we consider predation risk in marine bryozoans? In: Winston JE, Key MM, Hageman SJ (eds) Proc 14th Int Bryozool Assoc Meet, Boone, NC. Virginia Museum of Natural History Press, Martinsville, VA

Lindquist N, Hay ME (1996) Palatability and chemical defense of marine invertebrate larvae. Ecol Monogr 66: 431-450

Lippert H, Iken K (2003) Palatability and nutritional quality of marine invertebrates in a sub-Arctic fjord. J Mar Biol Assoc UK 83:1215-1219

Lombarte A, Olaso I, Bozzano A (2003) Ecomorphological trends in the Artedidraconidae (Pisces: Perciformes: Notothenioidei) of the Weddell Sea. Antarct Sci 15:211-218

Luczkovich JJ, Ward GP, Johnson JC, Christian RR, Baird D, Neckles H, Rizzo WM (2002) Determining the trophic guilds of fishes and macroinvertebrates in a seagrass food web. Estuaries 25:1143-1163

Mancinelli G, Rossi L (2001) Indirect, size-dependent effects of crustacean mesograzers on the Rhodophyta Gracilaria verrucosa (Hudson) Papenfuss: evidence from a short-term study in the Lesina Lagoon (Italy). Mar Biol 138:1163-1173

Martin D, Uriz MJ (1993) Chemical bioactivity of Mediterranean benthic organisms against embryos and larvae of marine invertebrates. J Exp Mar Biol Ecol 173:11-27

McCune B, Mefford MJ (1999) PC-Ord: multivariate analysis of ecological data, version 5. MJM Software Design, Gleneden Beach, OR

McKinney FK, Jackson JBC (1989) Bryozoan evolution. Unwin Hyman, Boston, MA

McKinney FK, Taylor PD, Lidgard S (2003) Predation on bryozoans and its reflection in the fossil record. In: Kelley $\mathrm{PH}_{\text {, }}$ Kowalewski M, Hansen T (eds) Predator-prey interactions in the fossil record. Kluwer Academic/Plenum, New York, p 239-261

Miller MC (1961) Distribution and food of the nudibranchiate Mollusca of the south of the Isle of Man. J Anim Ecol 30: 95-116

Morgado EH, Tanaka MO (2001) The macrofauna associated with the bryozoan Schizoporella errata (Walters) in southeastern Brazil. Sci Mar 65:173-181

Murray FV (1970) The reproduction and life history of Microginella minutissima (Tenison-Woods, 1876) (Gastropoda: Marginellidae). Mem Natl Mus Vic 31:31-35

Norton SF, Luczkovich JJ, Motta PJ (1995) The role of ecomorphological studies in the comparative biology of fishes. Environ Biol Fishes 44:287-304

Nybakken J, McDonald G (1981) Feeding mechanisms of West American Nudibranch feeding on Bryozoa, Cnidaria and Ascidiacea, with special respect to the radula. Malacologia 20:439-449

Osburn RC (1921) Bryozoa as food for other animals. Science 53:451-453

Padilla DK, Allen BJ (2000) Paradigm lost: reconsidering functional form and group hypotheses in marine ecology. J Exp Mar Biol Ecol 250:207-221

Peck LS, Barnes DKA (2004) Metabolic flexibility: the key to long-term evolutionary success in Bryozoa? Proc R Soc Lond B Biol Sci 271:S18-S21
Pederson EJ, Peterson MS (2002) Bryozoans as ephemeral estuarine habitat and a larval transport mechanism for mobile benthos and young fishes in the north-central Gulf of Mexico. Mar Biol 140:935-947

Pentreath RJ (1970) Feeding mechanisms and the functional morphology of podia and spines in some New Zealand ophiuroids (Echinodermata). J Zool 161:395-429

Piraino S, Bouillon J, Boero F (1992) Halocoryne epizoica (Cidaria, Hydrozoa), a hydroid that bites. Sci Mar 56: 141-147

Platell ME, Potter IC (2001) Partitioning of food resources amongst 18 abundant benthic carnivorous fish species in marine waters on the lower west coast of Australia. J Exp Mar Biol Ecol 261:31-54

Poitrineau K, Brown SP, Hochberg ME (2003) Defence against multiple enemies. J Evol Biol 16:1319-1327

Ryland JS (1976) Physiology and ecology of marine bryozoans. Adv Mar Biol 14:285-443

Sharp JH, Winson MK, Porter JS (2007) Bryozoan metabolites: an ecological perspective. Nat Prod Rep 24:659-673

Stekhoven JH Jr (1933) Die Nahrung von Oncholaimus dujardiniide Man. Zool Anz 101:167-168

Steneck RS (2001) Functional groups. In: Levin S (ed) Encyclopedia of biodiversity, Vol 1. Academic Press, San Diego, CA, p 121-139

Steneck RS, Watling L (1982) Feeding capabilities and limitation of herbivorous molluscs: a functional group approach. Mar Biol 68:299-319

Strenger A, Splechtna H (1978) Zum Auftreten und zur Ernährung von Echinus melo Lam. Zool Anz 200: $374-378$

Taylor RB (1998) Density, biomass and productivity of animals in four subtidal rocky reef habitats: the importance of small mobile invertebrates. Mar Ecol Prog Ser 172: $37-51$

Todd CD (1981) The ecology of nudibranch molluscs. Oceanogr Mar Biol Annu Rev 19:141-234

> Wacasey JW, Atkinson EG (1987) Energy values of marine benthic invertebrates from the Canadian Arctic. Mar Ecol Prog Ser 39:243-250

> Wahl M, Hay ME (1995) Associational resistance and shared doom: effects of epibiosis on herbivory. Oecologia 102: 329-340

Wahl M, Hay ME, Enderlein P (1997) Effects of epibiosis on consumer-prey interactions. Hydrobiologia 355:49-59

Wainwright PC, Bellwood DR (2002) Ecomorphology of feeding in coral reef fishes. In: Sale PF (ed) Coral reef fishes dynamics and diversity in a complex ecosystem. Academic Press, San Diego, CA, p 33-55

Walters LJ, Wethey DS (1991) Settlement, refuges, and adult body form in colonial marine invertebrates: a field experiment. Biol Bull 180:112-118

Walters LJ, Wethey DS (1996) Settlement and early postsettlement survival of sessile marine invertebrates on topographically complex surfaces: the importance of refuge dimensions and adult morphology. Mar Ecol Prog Ser 137: 161-171

Winston JE (1984) Why bryozoans have avicularia: a review of the evidence. Am Mus Novit 2789:1-26

Winston JE (1986a) Victims of avicularia. PSZN I: Mar Ecol 7: 193-199

Winston JE (1986b) An annotated checklist of coral-associated Bryozoa. Am Mus Novit 2859:1-39

Wyer D, King PE (1973) Relationships between some British littoral and sublittoral bryozoans and pycnogonids. In: Larwood GP (ed) Living and fossil Bryozoa. Academic Press, London, p 199-207 